\title{
EFFECTS OF ORGANIC PLANT EXTRACTS ON BEHAVIOR OF Sitophilus zeamais MOTS. (COLEOPTERA: CURCULIONIDAE) ADULTS
}

\author{
Leandro Prado Ribeiro ${ }^{1} \&$ José Djair Vendramim ${ }^{2}$
}

\begin{abstract}
${ }^{1}$ Empresa de Pesquisa Agropecuária e Extensão Rural de Santa Catarina/Centro de Pesquisa para Agricultura Familiar, Chapecó, SC, Brasil. E-mail: leandroribeiro@epagri.sc.gov.br

${ }^{2}$ Universidade de São Paulo/Escola Superior de Agricultura "Luiz de Queiroz” (USP/ESALQ), Piracicaba, SP, Brasil. Email: jdvendra@usp.br
\end{abstract}

\begin{abstract}
The aim of the present study was to evaluate the action of organic plant extracts from different parts of some species on host selection behavior of Sitophilus zeamais (Coleoptera: Curculionidade) adults. With the exception of extracts prepared from Aristolochia paulistana, all other tested plant extracts showed effect on behavior of S. zeamais adults, depending on concentration and solvent used in their preparation. The most pronounced repellent and/or deterrent effects were obtained with nonpolar extracts (in hexane and dichloromethane) of Annona montana, Annona mucosa, and Casearia sylvestris. On the other hand, ethanolic extracts from branches of C. sylvestris, leaves of A. montana, and leaves and seeds of A. mucosa were attractive and/or stimulant of feeding and/or oviposition of S. zeamais adults, depending on the concentration used. Thus, these extracts are promising sources of attractive compounds to be used in food baits in monitoring traps or even as repellents of stored grain pests.
\end{abstract}

Keywords: Maize weevil, allelochemicals, Annona montana, Annona mucosa, Casearia sylvestris

\section{EFEITO DE EXTRATOS ORGÂNICOS DE PLANTAS NO COMPORTAMENTO DE ADULTOS DE Sitophilus zeamais MOTS. (COLEOPTERA: CURCULIONIDAE)}

\section{RESUMO}

Objetivou-se, no presente estudo, avaliar a ação de extratos orgânicos de estruturas vegetais de diferentes espécies no comportamento de adultos de Sitophilus zeamais (Coleoptera: Curculionidade). Com exceção dos extratos oriundos de Aristolochia paulistana, todos os demais extratos testados causaram efeito no comportamento de adultos de $S$. zeamais, dependendo da concentração e do solvente utilizado na sua preparação. Os efeitos repelente e/ou deterrente mais pronunciados foram obtidos com 
os extratos mais apolares (em hexano e diclorometano) de Annona montana, Annona mucosa e Casearia sylvestris. Por outro lado, extratos etanólicos de ramos de C. sylvestris, de folhas de A. montana e de folhas e sementes de $A$. mucosa foram atraentes e/ou estimulantes de alimentação e/ou oviposição de adultos de S. zeamais, dependendo da concentração utilizada. Dessa forma, tais extratos são promissoras fontes de compostos atrativos passíveis de serem utilizados em iscas alimentares em armadilhas de monitoramento ou mesmo repelentes de pragas de grãos armazenados.

Palavras-chave: Gorgulho-do-milho, aleloquímicos, Annona montana, Annona mucosa, Casearia sylvestris

\section{INTRODUCTION}

The maize weevil, Sitophilus zeamais Motschulsky, 1855 (Coleoptera: Curculionidae), is a primary pest species of stored grains (LAZZARI \& LAZZARI, 2009). S. zeamais has a large number of alternative hosts, high biotic potential and capacity to survive at great depths in the grain mass (FARONI, 1992). In addition, the occurrence of cross-infestation, that is, the capacity of the insect to attack grains in the field and in warehouses, increases the damage magnitude of S. zeamais (LORINI et al., 2015). In Brazilian conditions, Picanço et al. (2004) reported losses of up to $30 \%$ in corn summer crops in Coimbra (MG) during pre-harvest.

The use of synthetic insecticides is the most widely method for the control of S. zeamais, mostly because of lack of alternative efficient control methods (BOYER et al., 2012). However, the use of chemical compounds has been compromised due to restricted availability of insecticides registered for

the control of this species and the consequent difficulty to switch active ingredients (UPADHYAY \& AHMAD, 2011) and occurrence of resistant populations (RIBEIRO et al., 2003). However, some studies have presented the viability of using bioactive compounds obtained from plants for pest control of stored grains (RIBEIRO et al., 2016).

Plants with insecticidal action have been used as an alternative method through products in the form of powders, oils and extracts for control of major pests of stored products in many countries of Latin America, Africa and Asia (GONÇALVES et al., 2015), showing toxicity via contact, ingestion and fumigation (ESTRELA et al., 2006). Plant substances cause mortality, repellency, oviposition inhibition, increased duration of larval development, and reduction in fertility and fecundity of adults (MARTINEZ 
\& VAN EMDEN, 2001). In addition to the direct application through homemade preparations, elucidation of the chemical structure of plant secondary metabolites (allelochemicals) allow the synthesis of new products more acceptable by the society. Identification, sequencing and cloning of genes responsible for gene expression of allelochemicals may allow the transfer of resistance to agricultural crops, eliminating the use of chemicals (COSTA \& MAIRESSE, 2009).

This study evaluated the action of organic extracts of plants with insecticidal activity at different stages of host selection behavior of adults of $S$. zeamais in choice tests using corn seeds as a substrate.

\section{MATERIAL AND METHODS}

\section{Establishment and maintenance rearing of Sitophilus zeamais}

The rearing of $S$. zeamais was established from specimens obtained from a population kept in the Laboratory of Food Irradiation and Radioentomology of Centro de Energia Nuclear na Agricultura (CENA/USP), in Piracicaba, São Paulo, Brazil.

Insects used in bioassays were reared in an air-conditioned room at $25 \pm 2^{\circ} \mathrm{C}$, relative humidity $60 \pm 10 \%$, photophase of $14 \mathrm{~h}$, and average luminosity 172 lux in 3-L glass bottles with the top sealed with fine cloth (voile). Wheat grains were used as substrate for the maintenance rearing of S. zeamais, which were previously exposed to $-10^{\circ} \mathrm{C}$, for at least $48 \mathrm{~h}$, in a domestic freezer to eliminate insect contaminants (SILVA-AGUAYO et al., 2006). After fumigation, the grains were kept in a temperaturecontrolled room, under the conditions mentioned previously, for $30 \mathrm{~d}$ to reach hygroscopic balance before use (RIBEIRO et al., 2013).

\section{Obtaining species and preparing plant extracts}

Data collection of plant species used in extract preparation are shown in Table 1. After collection, an exsiccate was obtained from each species, which were forwarded to specific identification to the following institutions: Department of Systematics and Evolution of Higher Plants/University of Vienna and Bioscience Institute of University of São Paulo (IB/USP), for identification of species of Annonaceae; Department of Biological Sciences of ESALQ/USP, for identification of species of Aristolochiaceae and E.S.A. Museum of the Department of Biological Sciences of ESALQ/USP, for identification of species of Salicaceae. 
Table 1. Species, botanical families and plant parts used in the study on Sitophilus zeamais, with their respective locations and collection dates

\begin{tabular}{|c|c|c|c|c|}
\hline Species & Botanical family & $\begin{array}{l}\text { Plant part } \\
\text { collected }\end{array}$ & Collection location & $\begin{array}{c}\text { Collection } \\
\text { data }\end{array}$ \\
\hline $\begin{array}{c}\text { Annona montana } \\
\text { Macfadyen }\end{array}$ & Annonaceae & $\begin{array}{l}\text { Leaves, branches } \\
\text { and seeds }\end{array}$ & $\begin{array}{c}\text { Campus ESALQ/USP, } \\
\text { Piracicaba, SP } \\
\text { (Lat.: } 22^{0} 42 \text { ' } 29 \text { ', } \mathrm{S} \text {, Long.: } \\
\left.47^{0} 37^{\prime} 36^{\prime}, \mathrm{O}\right)\end{array}$ & $01 / 22 / 2010$ \\
\hline $\begin{array}{c}\text { Annona mucosa } \\
\text { Jacquin }\end{array}$ & Annonaceae & $\begin{array}{l}\text { Leaves, branches } \\
\text { and seeds }\end{array}$ & $\begin{array}{c}\text { Campus ESALQ/USP, } \\
\text { Piracicaba, SP } \\
\text { (Lat.: } 22^{0} 42^{\prime} 26^{\prime}, \mathrm{S}, \text { Long.: } \\
\left.47^{0} 377^{\prime} 39 \text { ', }\right)\end{array}$ & $01 / 22 / 2010$ \\
\hline $\begin{array}{l}\text { Aristolochia } \\
\text { paulistana } \\
\text { Hoehne }\end{array}$ & Aristolochiaceae & Branches & $\begin{array}{l}\text { Dist. Coronel Finzito, } \\
\text { Erval Seco, RS } \\
\text { (Lat.: } 27^{0} 31 \text { ' } 54 \text { ', S, Long.: } \\
\quad 53^{0} 33 \text { ' } 13 \text { ', O) }\end{array}$ & $01 / 10 / 2010$ \\
\hline $\begin{array}{l}\text { Casearia } \\
\text { sylvestris } \\
\text { Swartz }\end{array}$ & Salicaceae & $\begin{array}{c}\text { Leaves and } \\
\text { branches }\end{array}$ & $\begin{array}{c}\text { Campus ESALQ/USP, } \\
\text { Piracicaba, SP } \\
\text { (Lat.: } 22^{0} 42^{\prime} 50^{\prime} \text { 'S, Long.: } \\
\left.47^{0} 37^{\prime} 36^{\prime}, \mathrm{O}\right)\end{array}$ & $01 / 16 / 2010$ \\
\hline
\end{tabular}

For the preparation of extracts, the plant structures collected were dehydrated in an oven at $40^{\circ} \mathrm{C}$ for 48-72 h. Later, the materials were ground in a knife mill and plant powders were obtained, which were stored separately by species and plant structure in a hermetically sealed glass until use.

Organic extracts were obtained by maceration, using as solvents (at ratio 1:5, w/v), in crescent order of polarity, hexane (polarity: 0.06), dichloromethane (polarity: 3.4) and ethanol (polarity: 5.2). For each solvent, extraction was made until exhaustion, using then the solvent with polarity immediately above. At each change of solvent, the macerate was filtered through filter paper and solvent of the remaining sample was eliminated in rotary evaporator at $40^{\circ} \mathrm{C}$ and pressure $-600 \mathrm{mmHg}$. After complete evaporation of the solvent in the airflow chamber, the extraction yield for each structure of plant species in the distinct solvents used was determined.

\section{Bioassays}

Bioassays were conducted in an air-conditioned room at $25 \pm 2^{\circ} \mathrm{C}$, relative humidity $60 \pm 10 \%$, photophase of $14 \mathrm{~h}$ and average luminosity 172 lux, under a complete randomized design. As a substrate to carry out the tests, whole corn seeds of hybrid AG 1051 (toothed yellow; semi-hard) were used, which were previously selected manually. 
To evaluate the effect of extracts on attractiveness of $S$. zeamais adults, 10 arenas (repetitions) were used, each consisting of five plastic Petri dishes $(6 \mathrm{~cm}$ in diameter and $2 \mathrm{~cm}$ high) mounted on a plastic base $(30 \times 30 \mathrm{~cm})$. In each arena, one of the dishes is fixed at the base center and connected to the others by means of plastic tubes of equal length.

In one of the Petri dishes (control), it was placed $10 \mathrm{~g}$ of corn seeds treated with the same solvent used for resuspension of extracts (control), while in other cases, it was placed corn samples treated with the respective extracts chosen at random within each bioassay. In the central recipient, 50 adults of $S$. zeamais were released, not sexed and aged between 10 and $20 \mathrm{~d}$. After $24 \mathrm{~h}$, the number of insects in each container was assessed.

\section{Data analysis}

The treatments were compared to each other by means of the repellency/deterrence index (R.I./D.I.) adapted from Lin et al. (1990), calculated by the formula R.I./D.I. $=2 \mathrm{G} /(\mathrm{G}+\mathrm{P})$, where $\mathrm{G}=$ $\%$ of insects in grain treated with the extract under test and $\mathrm{P}=\%$ of insects in grain in the control group. Based on R.I./D.I. and standard deviation obtained, it was determined the classification interval (Class.I.) for the averages of the treatments by the formula: Class.I. $=1 \pm t_{(n-1 ; \alpha: 0.05) X}(\mathrm{SD} / \sqrt{ } n)$; where $t=$ value of " $\mathrm{t}$ " charted; $\mathrm{SD}=$ standard deviation; $\mathrm{n}=$ number of repetitions. The extracts were considered neutral when the R.I./D.I. value remained within the Class.I. evaluated; repellent and/or deterrent when the R.I./D.I. value was below the lowest value obtained for Class.I.; and attractive and/or phagodeterrent when the R.I./D.I. values were higher than the highest Class.I. calculated.

\section{RESULTS AND DISCUSSION}

The time of evaluation adopted did not allow to distinguish between the possible effects of the extracts tested in the different stages of the host selection process of S. zeamais. As this step is an initial screening of a large number of extracts, the objective was only to detect bioactive effects, without the aim to characterize them in this first moment. The characterization of possible effects of plant extracts on host selection of $S$. zeamais should be the subject of future investigations.

Containers with corn seeds treated with hexane extracts at $300 \mathrm{ppm}$ of branches of $A$. montana and seeds and branches of $A$. тисоsa showed fewer insects attracted compared to boxes containing only corn (control) (Table 2), differing significantly according to the index adopted (R.I./D.I.). This shows the 
existence of repellent and/or deterrent effect of food and/or oviposition layer of these extracts for adult of $S$. zeamais. However, at 1,500 ppm, all hexane extracts were classified as repellents and/or deterrents of food and/or oviposition for adult S. zeamais, except for the hexane extract of branches of A. paulistana (Table 2). At this concentration, the extract of branches of $C$. sylvestris was the treatment that caused greater repellent and/or deterrent effect. These results show a bioactive effect of nonpolar extracts (hexanes) that depend on the concentration.

At a concentration of $300 \mathrm{ppm}$, only the dichloromethane extract prepared from seeds of $A$. muсosa caused significant effect on adults of $S$. zeamais, reducing the number of insects attracted compared to boxes containing only corn (control) (Table 3). With the increase of the concentration to 1,500 ppm, however, except for dichloromethane extracts of branches of A. paulistana and leaves and the branches of $A$. mucosa, all others reduced the attractiveness of $S$. zeamais adults for the treated samples (Table 3).

On the other hand, ethanolic extracts of leaves of $A$. montana and leaves and seeds of $A$. mucosa were classified as attractive and/or stimulants for feeding and/or oviposition when tested at a concentration of $300 \mathrm{ppm}$ (Table 4). However, at the concentration of 1,500 ppm of seed extract from $A$. mисоsa, it was repellent and/or deterrent for the weevil under study, while branch extracts of C. sylvestris caused attractive and/or stimulating effect of food and/or oviposition (Table 4). Therefore, not only does this finding highlights the behavior change of the insect due to the extract concentration used, but it also shows the diversity of substances in extracts obtained from the same plant structure and species, which are likely to cause different behavioral effects to $S$. zeamais, depending on the solvent used that leads to significant changes in the chemical profile of the derivatives obtained and, consequently, changes in their bioactivity. Similarly, these results confirm the chemical separation provided by organic solvents through the extraction method used, which was already found in chromatographic profiles obtained by thin-layer chromatography (TLC) and the spectroscopic analyses carried out previously (RIBEIRO et al., 2013, 2014).

The action of plant compounds can present itself at different stages of host selection behavior (VENDRAMIM \& CASTIGLIONI, 2000) by means of differential performance on the physiological mechanisms of insects. Thus, the repellent activity is revealed in plant extracts that have compounds with unpleasant and irritant odors to insects (PETERSON \& COATS, 2001), which act on olfactory receptors (SUKUMAR et al., 1991). However, food deterrence is a disorder associated to sensory mechanisms that cause reduced food consumption (ISMAN, 2006). For this author, the feeding behavior of insects 
depends on the integration of the central nervous system with the chemoreceptors located on the tarsi, buccal parts and oral cavity. The authors also reports that certain substances, such as azadirachtin, present in neem extracts, can act on the chemoreceptors, stimulating "specific deterrent cells" or blocking the phagostimulants, such as the "sugar receptor cells", inhibiting feeding. Nevertheless, some substances may affect the substrate characteristics, making it unsuitable for oviposition or even influencing the levels of oviposition stimulants in grains or susceptible varieties (GOMEZ et al., 1983), thus, causing oviposition deterrence.

Table 2. Attractiveness of Sitophilus zeamais adult to corn samples (10 g) treated with hexane extracts prepared from different species and/or plant parts at two concentrations*. Temperature: $25 \pm 2{ }^{\circ} \mathrm{C}$; R.H.: $60 \pm 10 \%$; photophase: 14 h; average luminosity: 172 lux

\begin{tabular}{|c|c|c|c|c|}
\hline Plant species & $\begin{array}{l}\text { Plant } \\
\text { part }\end{array}$ & $\begin{array}{c}\text { R.I./D.I. }^{1} \\
\text { (Mean } \pm \text { SD) }\end{array}$ & Class.I. $^{2}$ & Classification \\
\hline \multicolumn{5}{|c|}{300 ppm } \\
\hline \multirow{3}{*}{ Annona montana } & Seeds & $0.88 \pm 0.33$ & $1 \pm 0.24$ & Neutral \\
\hline & Leaves & $0.97 \pm 0.18$ & $1 \pm 0.13$ & Neutral \\
\hline & Branches & $0.88 \pm 0.12$ & $1 \pm 0.09$ & Repellent and/or deterrent \\
\hline \multirow{3}{*}{ Annona тисоsa } & Seeds & $0.63 \pm 0.28$ & $1 \pm 0.20$ & Repellent and/or deterrent \\
\hline & Leaves & $0.89 \pm 0.24$ & $1 \pm 0.17$ & Neutral \\
\hline & Branches & $0.74 \pm 0.26$ & $1 \pm 0.19$ & Repellent and/or deterrent \\
\hline Aristolochia paulistana & Branches & $1.01 \pm 0.49$ & $1 \pm 0.35$ & Neutral \\
\hline \multirow{2}{*}{ Casearia sylvestris } & Leaves & $0.88 \pm 0.51$ & $1 \pm 0.36$ & Neutral \\
\hline & Branches & $0.99 \pm 0.42$ & $1 \pm 0.30$ & Neutral \\
\hline \multicolumn{5}{|c|}{$1,500 \mathrm{ppm}$} \\
\hline \multirow{3}{*}{ Annona montana } & Seeds & $0.39 \pm 0.38$ & $1 \pm 0.27$ & Repellent and/or deterrent \\
\hline & Leaves & $0.47 \pm 0.42$ & $1 \pm 0.30$ & Repellent and/or deterrent \\
\hline & Branches & $0.68 \pm 0.48$ & $1 \pm 0.34$ & Repellent and/or deterrent \\
\hline \multirow{3}{*}{ Annona тисоsа } & Seeds & $0.21 \pm 0.19$ & $1 \pm 0.13$ & Repellent and/or deterrent \\
\hline & Leaves & $0.53 \pm 0.50$ & $1 \pm 0.36$ & Repellent and/or deterrent \\
\hline & Branches & $0.44 \pm 0.35$ & $1 \pm 0.25$ & Repellent and/or deterrent \\
\hline Aristolochia paulistana & Branches & $1.09 \pm 0.35$ & $1 \pm 0.25$ & Neutral \\
\hline \multirow{2}{*}{ Casearia sylvestris } & Leaves & $0.48 \pm 0.30$ & $1 \pm 0.21$ & Repellent and/or deterrente \\
\hline & Branches & $0.12 \pm 0.16$ & $1 \pm 0.11$ & Repellent and/or deterrent \\
\hline
\end{tabular}

${ }^{1}$ R.I./D.I.: repellence and/or deterrence index;

${ }^{2}$ Class.I.: Classification interval;

* In a solution volume of $30 \mathrm{~L} \mathrm{t}^{-1}$. 
Table 3. Attractiveness of Sitophilus zeamais adult to corn samples (10 g) treated with dichloromethane extracts prepared from different species and/or plant parts at two concentrations*. Temperature: $25 \pm 2{ }^{\circ}$ C; R.H.: $60 \pm 10 \%$; photophase: $14 \mathrm{~h}$; average luminosity: 172 lux

\begin{tabular}{|c|c|c|c|c|}
\hline Plant species & $\begin{array}{l}\text { Plant } \\
\text { part }\end{array}$ & $\begin{array}{c}\text { R.I./D.I. }{ }^{1} \\
(\mathrm{Mean} \pm \mathrm{SD})\end{array}$ & Class.I. $^{2}$ & Classification \\
\hline \multicolumn{5}{|c|}{300 ppm } \\
\hline \multirow{3}{*}{ Annona montana } & Seeds & $0.82 \pm 0.48$ & $1 \pm 0.34$ & Neutral \\
\hline & Leaves & $1.14 \pm 0.35$ & $1 \pm 0.25$ & Neutral \\
\hline & Branches & $1.21 \pm 0.42$ & $1 \pm 0.30$ & Neutral \\
\hline \multirow{3}{*}{ Annona тисоsa } & Seeds & $0.65 \pm 0.32$ & $1 \pm 0.23$ & Repellent and/or deterrent \\
\hline & Leaves & $1.09 \pm 0.27$ & $1 \pm 0.19$ & Neutral \\
\hline & Branches & $0.84 \pm 0.46$ & $1 \pm 0.33$ & Neutral \\
\hline Aristolochia paulistana & Branches & $1.24 \pm 0.52$ & $1 \pm 0.37$ & Neutral \\
\hline \multirow{2}{*}{ Casearia sylvestris } & Leaves & $1.09 \pm 0.58$ & $1 \pm 0.41$ & Neutral \\
\hline & Branches & $0.85 \pm 0.72$ & $1 \pm 0.51$ & Neutral \\
\hline \multicolumn{5}{|c|}{$1,500 \mathrm{ppm}$} \\
\hline \multirow{3}{*}{ Annona montana } & Seeds & $0.35 \pm 0.33$ & $1 \pm 0.23$ & Repellent and/or deterrent \\
\hline & Leaves & $0.89 \pm 0.45$ & $1 \pm 0.32$ & Neutral \\
\hline & Branches & $0.31 \pm 0.30$ & $1 \pm 0.21$ & Repellent and/or deterrent \\
\hline \multirow{3}{*}{ Annona тисоsа } & Seeds & $0.29 \pm 0.37$ & $1 \pm 0.26$ & Repellent and/or deterrent \\
\hline & Leaves & $0.73 \pm 0.38$ & $1 \pm 0.28$ & Neutral \\
\hline & Branches & $0.71 \pm 0.44$ & $1 \pm 0.32$ & Neutral \\
\hline Aristolochia paulistana & Branches & $0.93 \pm 0.39$ & $1 \pm 0.28$ & Neutral \\
\hline \multirow{2}{*}{ Casearia sylvestris } & Leaves & $0.40 \pm 0.36$ & $1 \pm 0.26$ & Repellent and/or deterrent \\
\hline & Branches & $0.18 \pm 0.20$ & $1 \pm 0.14$ & Repellent and/or deterrent \\
\hline
\end{tabular}

${ }^{1}$ R.I./D.I.: repellence and/or deterrence index;

${ }^{2}$ Class.I.: Classification interval;

* In a solution volume of $30 \mathrm{~L} \mathrm{t}^{-1}$.

In this study, the extracts of branches of $C$. sylvestris in hexane and dichloromethane were the treatments with the lowest R.I./D.I. and consequently the most promising effects. Hypothetically, this bioactive effect observed on $S$. zeamais may be related to the occurrence of clerodanic diterpenes, which have been frequently isolated in different structures of $C$. sylvestris (CARVALHO et al., 2009; WANG et al., 2009). According to Rosselli et al. (2004), clerodanic diterpenes isolated from aerial part of 
Scutellaria sieberi (Lamiaceae) cause a potent anti-feeding effect to larvae of Spodoptera littoralis (Boisduval) (Lepidoptera: Noctuidae), which corroborates the hypothesis raised.

Table 4. Attractiveness of Sitophilus zeamais adults to corn samples ( $10 \mathrm{~g})$ treated with ethanolic extracts prepared from different species and/or plant parts at two concentrations*. Temperature: $25 \pm 2{ }^{\circ} \mathrm{C}$; R.H.: $60 \pm 10 \%$; photophase: 14 h; average luminosity: 172 lux

\begin{tabular}{|c|c|c|c|c|}
\hline Plant species & $\begin{array}{l}\text { Plant } \\
\text { part }\end{array}$ & $\begin{array}{c}\text { R.I./D.I. }{ }^{1} \\
(\mathrm{Mean} \pm \mathrm{SD})\end{array}$ & Class.I. $^{2}$ & Classification \\
\hline \multicolumn{5}{|c|}{300 ppm } \\
\hline \multirow{3}{*}{ Annona montana } & Seeds & $0.83 \pm 0.28$ & $1 \pm 0.23$ & Neutral \\
\hline & Leaves & $1.37 \pm 0.31$ & $1 \pm 0.26$ & Attractive and/or stimulant \\
\hline & Branches & $1.25 \pm 0.42$ & $1 \pm 0.35$ & Neutral \\
\hline \multirow{3}{*}{ Annona тисова } & Seeds & $1.33 \pm 0.26$ & $1 \pm 0.21$ & Attractive and/or stimulant \\
\hline & Leaves & $1.35 \pm 0.21$ & $1 \pm 0.17$ & Attractive and/or stimulant \\
\hline & Branches & $1.15 \pm 0.31$ & $1 \pm 0.26$ & Neutral \\
\hline Aristolochia paulistana & Branches & $1.13 \pm 0.38$ & $1 \pm 0.31$ & Neutral \\
\hline \multirow{2}{*}{ Casearia sylvestris } & Leaves & $1.14 \pm 0.44$ & $1 \pm 0.36$ & Neutral \\
\hline & Branches & $1.09 \pm 0.39$ & $1 \pm 0.32$ & Neutral \\
\hline \multicolumn{5}{|c|}{ 1,500 ppm } \\
\hline \multirow{3}{*}{ Annona montana } & Seeds & $0.75 \pm 0.45$ & $1 \pm 0.37$ & Neutral \\
\hline & Leaves & $1.17 \pm 0.52$ & $1 \pm 0.43$ & Neutral \\
\hline & Branches & $1.17 \pm 0.54$ & $1 \pm 0.45$ & Neutral \\
\hline \multirow{3}{*}{ Annona тисоsa } & Seeds & $0.33 \pm 0.34$ & $1 \pm 0.28$ & Repellent and/or deterrent \\
\hline & Leaves & $1.16 \pm 0.46$ & $1 \pm 0.38$ & Neutral \\
\hline & Branches & $0.90 \pm 0.51$ & $1 \pm 0.42$ & Neutral \\
\hline Aristolochia paulistana & Branches & $1.08 \pm 0.57$ & $1 \pm 0.47$ & Neutral \\
\hline \multirow{2}{*}{ Casearia sylvestris } & Leaves & $1.28 \pm 0.41$ & $1 \pm 0.34$ & Neutral \\
\hline & Branches & $1.31 \pm 0.34$ & $1 \pm 0.28$ & Attractive and/or stimulant \\
\hline
\end{tabular}

${ }^{1}$ R.I./D.I.: repellence and/or deterrence index;

${ }^{2}$ Class.I.: Classification interval;

* In a solution volume of $30 \mathrm{~L} \mathrm{t}^{-1}$.

Studies on the effect of substances extracted from Annonaceae on insect behavior are rather scarce. Ukeh et al. (2008) found that the application of seed powder of Monodora myristica to corn seeds provides significant oviposition deterrence for $S$. zeamais and suppresses entirely the $\mathrm{F}_{1}$ progeny at doses 
greater than $5 \%(\mathrm{w} / \mathrm{w})$. More promising results were obtained with essential oil of Mkilua fragrans, which caused repellent activity to Anopheles gambiae Giles (Diptera: Culicidae) more pronounced than DEET (N,N-diethyl-3-toluamide), active ingredient of synthetic commercial repellents (ODALO et al., 2005).

On the other hand, extracts from branches of A. paulistana caused no effect on the behavior of $S$. zeamais at any of the concentrations tested for the three solvents used. Unlike the results obtained, Pinto et al. (2009) found that the aristolochic acid extracted from A. chilensis causes stimulating effect to feeding in larvae and oviposition to females of Battus polydamas archidamas (Boisduval) (Lepidoptera: Papilionidae) and that this substance may even act on determining oviposition sites of females of this Lepidoptera during host selection. Lajide et al. (1993), on the other hand, found phagodeterrent effect of root extract of A. albida to Spodoptera litura (F.) (Lepidoptera: Noctuidae) larvae, and this activity was attributed to a free carboxylic group situated near a nitro group of aristolochic acid structure. Therefore, it is observed that the compounds present in Aristolochia can present distinct effects depending on the species of the target insect.

\section{CONCLUSIONS}

Nonpolar extracts (in hexane and dichloromethane) of A. montana, A. mucosa and C. sylvestris cause pronounced repellent and/or deterrent effects to feeding and/or oviposition of S. zeamais. In addition, ethanolic extracts from branches of $C$. sylvestris, leaves of $A$. montana and leaves and seeds of A. тисоs $a$ are attractive and/or stimulant of feeding and/or oviposition of adults of S. zeamais, depending on the concentration used. Therefore, the results obtained in this study point to prospects for more detailed studies on the use of these compounds with attractive and/or stimulating effects on feeding baits in monitoring traps, enabling more efficient and early detection of infestations. In addition, repellent compounds can be used to keep insects out of factories and warehouses, away from products to be protected.

\section{REFERENCES}

BOYER, S.; ZHANG, H.; LEMPERIERE, G. 2012. A review of control methods and resistance mechanisms in stored-products insects. Bulletin of Entomological Research, Farnham Royal, v. 102, n. 2, p. 213-229. 
CARVALHO, E.S.; SANTOS, A.G.; CAVALHEIRO, A.J. 2009. Identificação de diterpenos clerodânicos em diferentes órgãos de Casearia sylvestris Swartz. Revista de Ciências Farmacêuticas Básica e Aplicada, Araraquara, v.30, n.3, p.277-284.

COSTA, E.C.; MAIRESSE, L.A. 2009. Contaminação ambiental pela agricultura e as novas perspectivas com a moderna biotecnologia. Santa Maria: Orium, 162p.

ESTRELA, J.L.V.; FAZOLIN, M.; CATANI, V.; ALÉCIO, M.R.; LIMA, M.S. 2006. Toxicidade de óleos essenciais de Piper aduncum e Piper hispidinervum em Sitophilus zeamais. Pesquisa Agropecuária Brasileira, Brasília, v.41, p.217-222.

FARONI, L.R.D’A. 1992. Manejo das pragas dos grãos armazenados e sua influência na qualidade do produto final. Revista Brasileira de Armazenamento, Viçosa, v.17, n. 1/2, p.36-43.

GOMEZ, L.A.; RODRIGUEZ, J.G.; PONELEIT, C.G.; BLAKE, D.F.; SMITH JUNIOR, C.R. 1983. Relationship between some characteristics of the corn kernel pericarp and resistance to the rice weevil (Coleoptera: Curculionidae). Journal of Economic Entomology, Lanham, v.76, p.797-800.

GONÇALVES, G.L.P.; RIBEIRO, L.P.; GIMENES, L.; VIEIRA, P.C.; SILVA, M.F.G.F.; FORIM, M.F.; FERNANDES, J.B.; VENDRAMIM, J.D. 2015. Lethal and sublethal toxicities of Annona sylvatica (Magnoliales: Annonaceae) extracts to Zabrotes subfasciatus (Coleoptera: Chrysomelidae: Bruchinae). The Florida Entomologist, Gainesville, v.98, n.3, p.921-928.

ISMAN, M.B. 2006. Botanical insecticides, deterrents, and repellents in modern agriculture and an increasingly regulated word. Annual Review of Entomology, Palo Alto, v.51, p.45-66.

LAJIDE, L.; ESCOUBAS, P.; MIZUTANI, J. 1993. Antifeedant activity of metabolites of Aristolochia albida against the tobacco cutworm, Spodoptera Iitura. Journal of Agriculture and Food Chemistry, Davis, v.41, p.669-673.

LAZZARI, S.M.N.; LAZZARI, F.A. 2009. Insetos-praga de grãos armazenados. In: PANIZZI, A.R.; PARRA, J.R.P. (Ed.). Bioecologia e nutrição de insetos. Brasília: Embrapa Informação Tecnológica, p.667-732.

LIN, H.; KOGAN, M.; FISCHER, D. 1990. Induced resistance in soybean to the Mexican bean beetle (Coleoptera: Coccinellidae): comparisons of inducing factors. Environmental Entomology, College Park, v.19, p.1852-1857.

LORINI, I.; KRZYZANOWSKI, F.C.; FRANÇA-NETO, J.B.; HENNING, A.A.; HENNING, F.A. 2015. Manejo integrado de pragas de grãos e sementes armazenadas. Brasília: EMBRAPA, 84p.

MARTINEZ, S.S.; VAN EMDEN, H.F. 2001. Growth disruption, abnormalities and mortality of Spodoptera littoralis (Boisduval) (Lepidoptera: Noctuidae) caused by azadirachtin. Neotropical Entomology, Londrina, v.30, n.1, p.113-125.

ODALO, J.O.; OMOLO, M.O.; MALEBO, H.; ANGIRA, J.; NJERU, P.M.; NDIEGE, I.O.; HASSANALI, A. 2005. Repellency of essential oils of some plants from the Kenyan coast against Anopheles gambiae. Acta Tropica, Basel, v.95, p.210-218

PETERSON, C.; COATS, J. 2001. Insect repellents - past, present and future. Pesticide Outlook, Lisboa, p.154-158.

PICANÇO, M.C.P.; SEMEÃO, A.A.; GALVÃO, J.C.C.; SILVA, E.M. 2004. Fatores de perdas em cultivares de milho safrinha. Acta Scientiarum Agronomy, Maringá, v.26, n.2, p.161-167.

PINTO, C.F.; TRONCOSO, A.J.; URZÚA, A.; NIEMEYER, H. 2009. Aristolochic acids affect the feeding behaviour and development of Battus polydamas archidamas larvae (Lepidoptera: Papilionidae: Troidini). European Journal of Entomology, Branisovska, v.106, p.357-361.

RIBEIRO, B.M.; GUEDES, R.N.C.; OLIVEIRA, E.E.; SANTOS, J.P. 2003. Insecticide resistance and synergism in Brazilian populations of Sitophilus zeamais (Coleoptera: Curculionidae). Journal of Stored Product Research, Oxford, v.39, n.1, p.21-31. 
RIBEIRO, L.P.; VENDRAMIM, J.D.; ANDRADE, M.S.; BICALHO, K.U.; SILVA, M.F.G.F.; VIEIRA, P.C.; FERNANDES, J.B. 2014. Tropical plant extracts as sources of grain-protectant compounds against Sitophilus zeamais Motschulsky (Coleoptera: Curculionidae). Neotropical Entomology, Londrina, v.43, n.5, p.470-482.

RIBEIRO, L.P.; VENDRAMIM, J.D.; BICALHO, K.U.; ANDRADE, M.S.; FERNANDES, J.B.; MORAL, R.A.; DEMÉTRIO, C.G.B. 2013. Annona mucosa Jacq. (Annonaceae): a promising source of bioactive compounds against Sitophilus zeamais Mots. (Coleoptera: Curculionidae). Journal of Stored Products Research, Oxford, v.55, p.6-14.

RIBEIRO, L.P.; VENDRAMIM, J.D.; GONÇALVES, G.L.P.; ANSANTE, T.F.; GLORIA, E.M.; LOPES, J.C.; MELLO-SILVA, R.; FERNANDES, J.B. 2016. Searching for promising sources of grain protectors in extracts from Neotropical Annonaceae. Boletín Latinoamericano y del Caribe de Plantas Medicinales y Aromáticas, Santiago, v.15, n.4, p.215 - 232.

ROSSELLI, S.; MAGGIO, A.; PIOZZI, F.; SIMMONDS, M.S.J.; BRUNO, M. 2004. Extremely potent antifeedant neo-clerodane derivatives of scutecyprol A. Journal of Agriculture and Food Chemistry, Davis, v.52, p.7867-7871.

SILVA-AGUAYO, G.; GALLO, R.H.; VARGAS, M.T.; RUIZ, F.O.; BUSTOS, P.C.; FIGUEIROA, G.B. 2006. Evaluación de boldo (Peumus boldus Molina) y cal para el control de Sitophilus zeamais Motschulsky. Agrociencia, Chapingo, v. 40, p. 219-228.

SUKUMAR, K.; PERICH, J.M.; BOOBAR, R.L. 1991. Botanical derivatives in mosquito control: a review. Journal of American Mosquito Control Association, Fresno, v.7, p.210-237.

UKEH, D.A.; ARONG, G.A.; OGBAN, E.I. 2008. Toxicity and oviposition deterrence of Piper guineense (Piperaceae) and Monodora myristica (Annonaceae) against Sitophilus zeamais (Motsch.) on stored maize. Journal of Entomology, Dubai, v.5, n.4, p.295-299.

UPADHYAY, R.K.; AHMAD, S. 2011. Management strategies for control of stored grain insect pests in farmer stores and public warehouses. Journal of Entomology, Dubai, v.5, n.4, p.295-299. World Journal of Agricultural Sciences, Dubai, v.7, n.5, p.527-549.

VENDRAMIM, J.D.; CASTIGLIONI, E. 2000. Aleloquímicos, resistência de plantas e plantas inseticidas. In: GUEDES, J.C.; COSTA, I.D.; CASTIGLIONI, E. (Org.) Bases e Técnicas do Manejo de Insetos. Santa Maria: Pallotti, p.113-128.

WANG, W.; ALI, Z.; LI, X.C.; SMILLIE, T.A.; GUO, D.A.; KHAN, I.A. 2009. New clerodane diterpenoids from Casearia sylvestris. Fitoterapia, Milano, v.80, p.404-407. 